\title{
Spatial Distribution of Dengue Hemorrhagic Fever (DHF) in Urban Setting of Bandung City
}

\author{
Titik Respati, ${ }^{1}$ Ardini Raksanagara, ${ }^{2}$ Henni Djuhaeni, ${ }^{2}$ Asep Sofyan ${ }^{3}$ \\ ${ }^{1}$ Department of Public Heath, Faculty of Medicine, Universitas Islam Bandung, Bandung, Indonesia, \\ ${ }^{2}$ Department of Public Heath, Faculty of Medicine, Universitas Padjadjaran, Bandung, Indonesia, \\ 3Department of Environmental Engineering, Faculty of Civil and Environmental Engineering, \\ Institut Teknologi Bandung, Bandung, Indonesia
}

\begin{abstract}
The proximity of urban area provides fertile ground for the exchange of bacteria, virus and other health problem. One of the diseases which have a close relationship with the environment and people interaction is dengue. At present, it still is one of the major health problems for Indonesia. One method to understand the disease is by using spatial analysis that the prevention program can be focusing on the area most affected. This study aims to analyze the spatial distribution of dengue cases in Bandung city. The method used was the mapping of dengue cases using geographic information system (GIS) with ArcView software. Data were collected from August 2015 to March 2016 in Bandung city. Results showed that dengue cases increased with fluctuated hyperendemic years especially in the year 2009, 2012, and 2013. Spreading pattern of the disease was from north of Bandung to east. The conclusion of this study dengue cases in Bandung city showed an increased trend with fluctuated hyperendemic year especially in the year 2009, 2012, and 2013. Pockets of highest reported cases were found in north to middle and east for the whole year. The spread of this disease, especially in east Bandung, showed wider affected areas in the observed year. Land usage for residential purposes without good development plan might be on factors that increase the disease transmission.
\end{abstract}

Key words: Dengue hemorrhagic fever, GIS, spatial distribution

\section{Distribusi Spasial Kasus Demam Berdarah Dengue di Daerah Urban Kota Bandung}

\begin{abstract}
Abstrak
Kedekatan dalam wilayah urban memberikan kemudahan dalam pertukaran bakteri, virus, dan masalah kesehatan lainnya. Salah satu penyakit yang erat hubungannya dengan kedekatan pemukiman, lingkungan, dan interaksi manusia adalah demam berdarah dengue (DBD). Sampai saat ini DBD masih menjadi masalah kesehatan di Indonesia. Pencegahan suatu penyakit akan lebih mudah dilakukan apabila pemahaman mengenai penyakit tersebut sudah dapat dilakukan dengan baik. Dengan pemetaan (distribusi spasial), kasus DBD akan lebih mudah dimonitor sehingga program pencegahan dapat difokuskan pada wilayah dengan angka kejadian yang tinggi. Penelitian ini bertujuan melihat distribusi spasial kasus DBD mempergunakan geografic information system (GIS) di Kota Bandung. Metode penelitian ini adalah pemetaan kasus di wilayah tertentu dengan GIS menggunakan ArcView software menggunakan data kasus DBD dan data spasial dilaksanakan pada tahun 2015 di Kota Bandung. Hasil penelitian kasus DBD di Kota Bandung menunjukkan peningkatan dengan pola tahun hiperendemik berfluktuasi terutama pada tahun 2009, 2012, dan 2013. Pola pergerakan kasus tampak berawal dari arah utara menuju timur. Kantong wilayah dengan kasus DBD yang tinggi terkumpul di daerah utara menuju timur Kota Bandung sepanjang tahun. Simpulan penelitian ini, penyebaran kasus di wilayah Bandung menunjukkan daerah sebaran yang semakin besar dari tahun ke tahun. Pemanfaatan lahan sebagai pemukiman memiliki keterkaitan terhadap kejadian DBD.
\end{abstract}

Kata kunci: Demam berdarah dengue, distribusi spasial, GIS

Received: 19 May 2017; Revised: 23 November 2017; Accepted: 6 December 2017; Published: 27 December 2017

Corespondence: Dr. Titik Respati, drg., M.Sc.P.H. Department of Public Health, Faculty of Medicine, Universitas Islam Bandung. Jln. Tamansari No. 22, Bandung 40116, West Java, Indonesia. Telepon: (6222) 4203368. Fax: (6222) 4231213. HP: 62817229130. E-mail: titik.respati@unisba.ac.id; titik.respati@gmail.com 


\section{Introduction}

Urban population in 2014 comprised of $54 \%$ total world population, an increased from $34 \%$ in the 1960s'. World Health Organisation (WHO) predicted that urban population increased $1.84 \%$ per year from 2015 to 2020, $1.63 \%$ per year from 2020 to 2025 , and $1.44 \%$ per year from 2025 dan 2030. ${ }^{1}$ The closeness in urban areas gave easy access to exchanges of bacteria, virus, and other health problems. A disease which is closely related to residential areas, domestic environment and human interaction was dengue. ${ }^{1}$

Indonesia is a dengue hemorrhagic fever or DHF endemic areas since 1968 with the spread of this disease found in 33 provinces and 440 districts/cities. Dengue hemorrhagic fever (DHF) incidences were 41.25/100,000 population, and case fatality rate (CFR) of $0.7 \%$ in $2013 .^{2}$ West Java provinces was one of the provinces with the highest number of DHF cases in Indonesia. In 2011 and 2012 there were 19,663 and 19,739 DHF cases respectively. Bandung city has the highest DHF cases in West Java with 3,822; 5,057; 5,127 and 3,132 cases in 2011, 2012, 2013, and 2014 respectively. ${ }^{3}$

Disease prevention will be much easier whenever the understanding of the diseases including its patterns is understood. An approach to understanding the disease was by mapping the cases according to areas. Geographic information system (GIS) 4 is one method that can be used as mapping tools for DHF cases in Bandung city. ${ }^{5}$ Dengue hemorrhagic fever cases mapping can be used to monitor areas with a different number of DHF cases to be monitored. The map can also be used for prevention activities which will be conducted in the highest cases of DHF for examples. These articles describe the spatial distribution of DHF in urban areas.

\section{Methods}

This was an observational study using several data set collected from November 2014 to August 2015. Data set used were 1) DHF cases reported to Bandung City District Health Office from 2009-2014; 2) sub-district elevation, and 3) land coverage. Geographic information system with software ArcView4 used to map DHF cases for Bandung city based on years and sub-districts.

\section{Results}

Data of DHF cases gathered from Bandung City Health Office was based on reports from 20 hospitals and Bandung City Health Centers from 2009-2014. There were a total of 27,978 DHF cases reported in Bandung city during six years of reports. The highest cases happened in 2009 $(6,751$ cases), followed by 5,757 cases in 2013 and 5,103 cases in 2012. The lowest cases reported in 2014 (3,088 cases) with 61 death caused by DHF in six years was reported which showed the case fatality rate of $0.2 \%$.

Figure 1 is the line chart of DHF cases from $1^{\text {st }}$ January 2009 to $31^{\text {st }}$ December 2014. In year 2009-2010 there were some days with very high DHF incidences with maximum reported cases of 140 in a day. Dengue hemorrhagic fever cases peaked in 2010, however since 2011 to $31^{\text {st }}$ December 2014 the cases reported were relatively stable with some variation. Figure 2 showed a significant decreased from almost $1 \%$ in year 2000

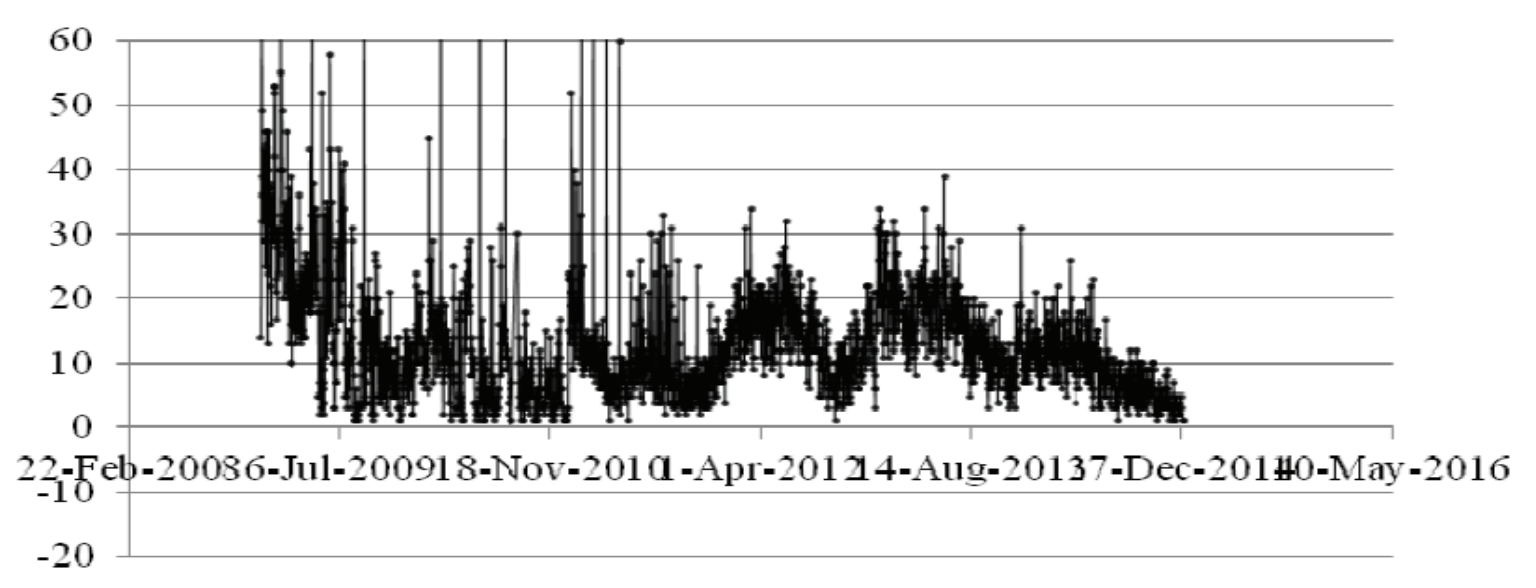

Figure 1 DHF Cases in Bandung City Year 2009-2014 


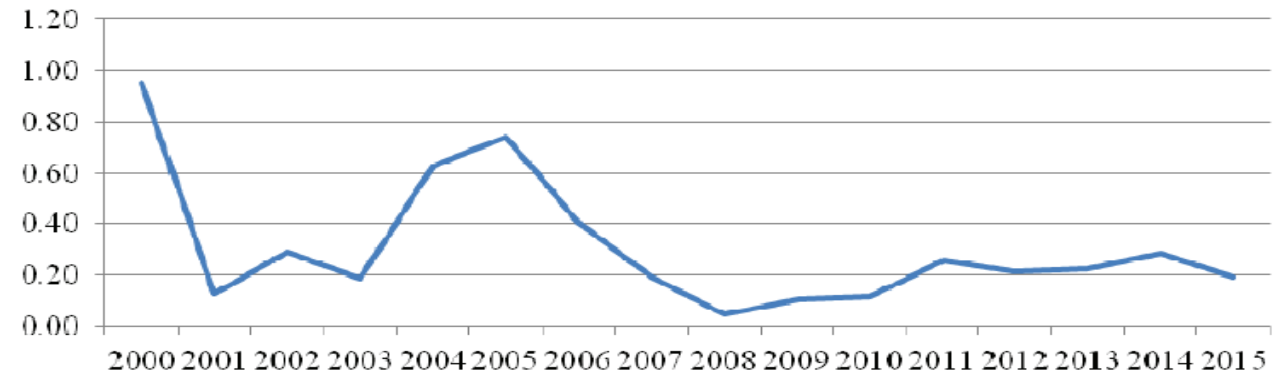

Figure 2 DHF Case Fatality Rate in Bandung City Year 2000-2015

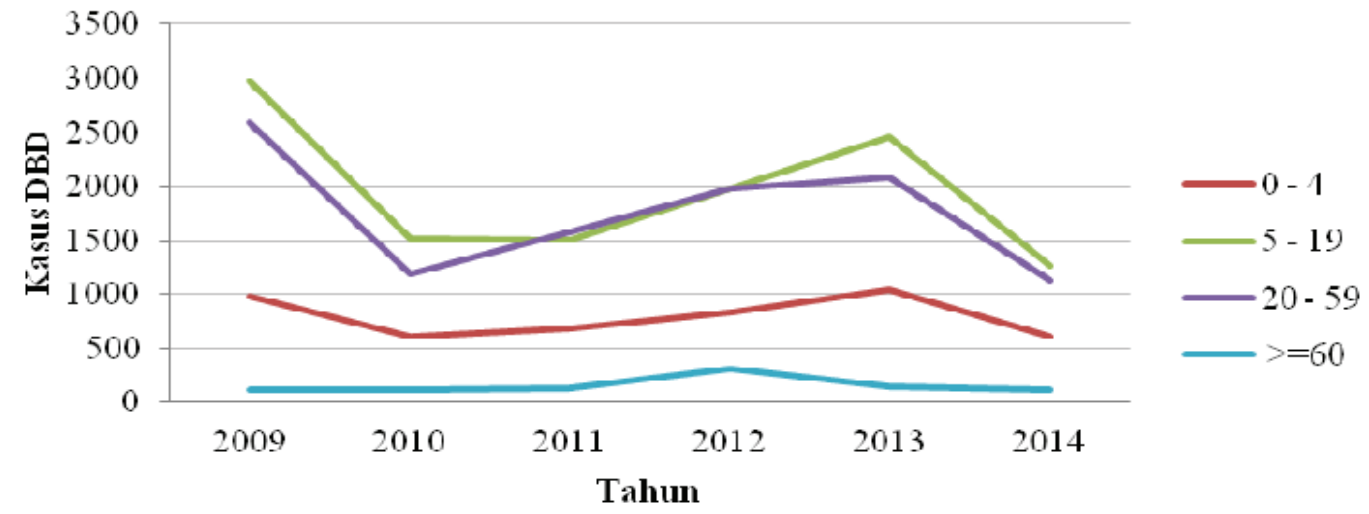

Figure 3 DHF Cases in Bandung City based on Age Group Year 2009-2014
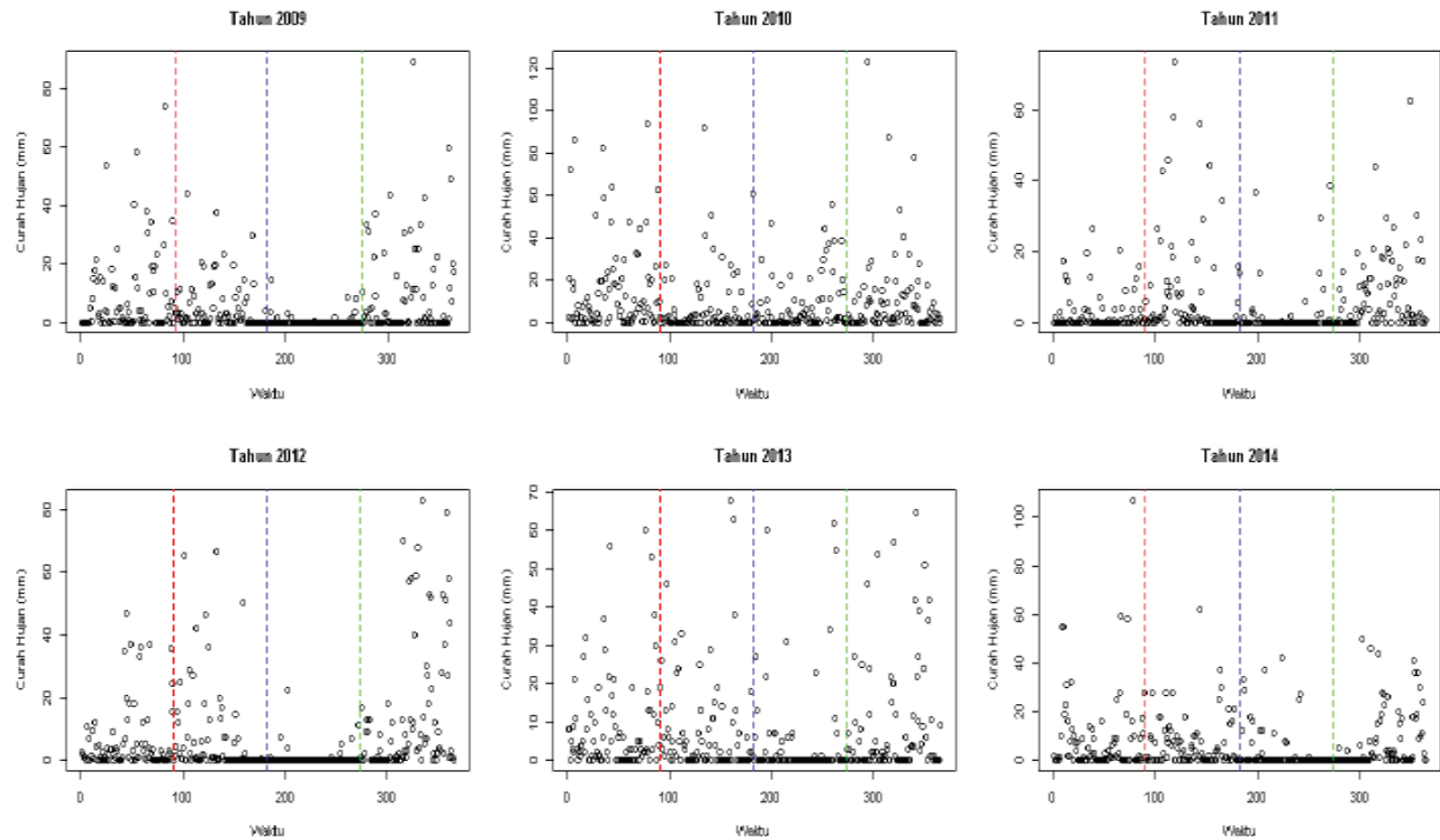

Figure 4 Scatter Plot Diagram of Quarterly DHF Cases in Bandung City Year 2009-2014 Notes: vertical lines showed quarter with quarter I from $1^{\text {st }}$ January to $31^{\text {st }}$ March; quarter II from $1^{\text {st }}$ April to $31^{\text {st }}$ June; quarter III from $1^{\text {st }}$ July to $30^{\text {st }}$ September; and quarter IV from $1^{\text {st }}$ October to $31^{\text {st }}$ December 


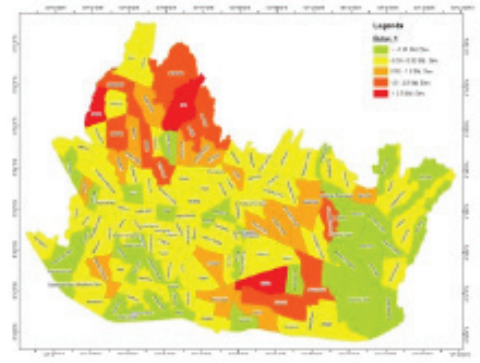

January

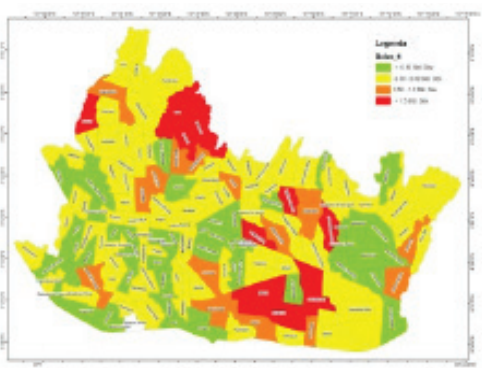

April

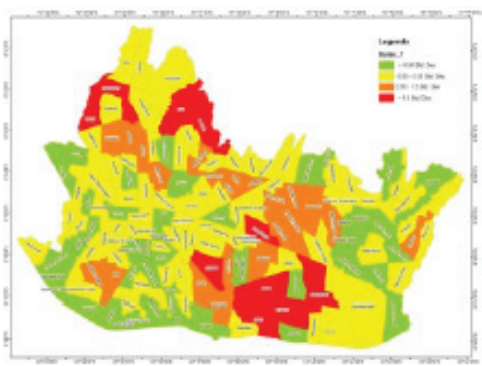

July

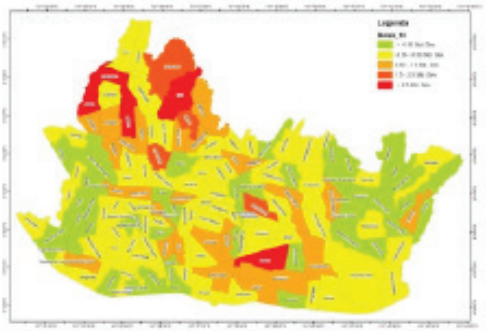

October

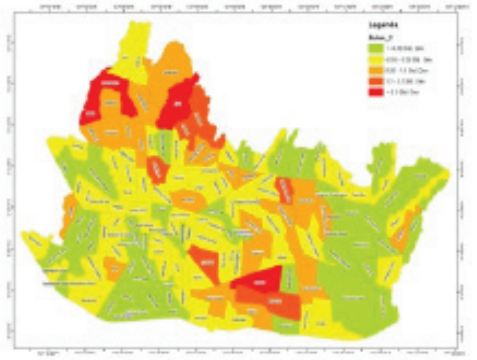

February

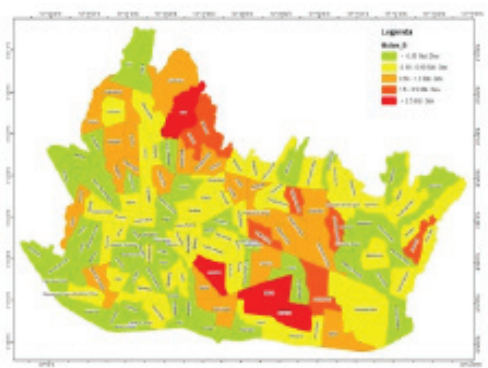

May

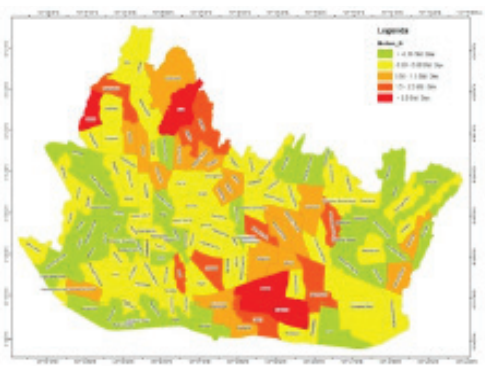

August

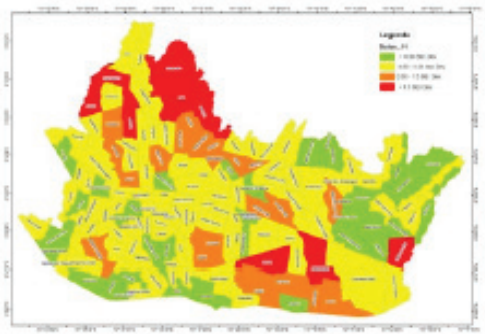

November

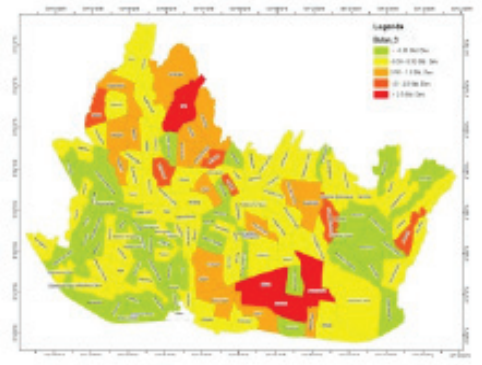

March

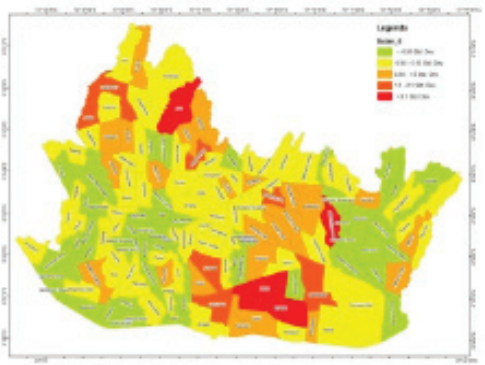

June

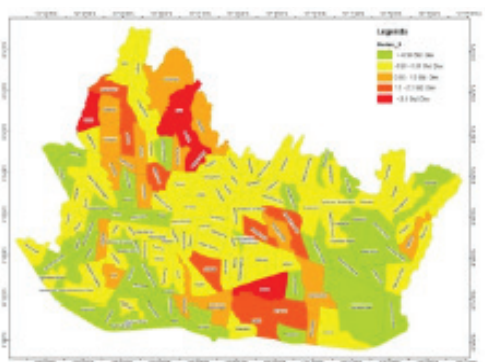

September

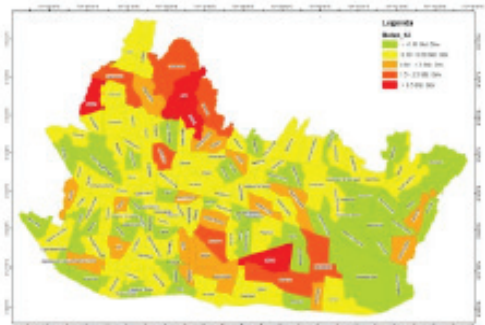

December

Figure 5 Monthly DHF Spatial Distribution in Bandung City from 2009-2014

to $0,2 \%$ in year 2015 and peaked in 2000 and 2005. Figure 3 showed dengue reported mostly from people age $5-19$ years old and $20-59$ years old and least for people aged $>60$ years old. Cases on productive age groups increased in 2009 and 2013. Figure 4 showed DHF cases were decreased in quarter III and increased significantly in quarter IV in 2009 and 2014. Overall there was an increased during quarter IV every year.

Figure 5 showed DHF spread was highest around north and middle Bandung city with northern part always reported the highest number of cases. The pattern of DHF cases from 2009 until 2014 started from north of Bandung heading east. Figure 6 showed DHF cases spatial distribution per year in Bandung city. 


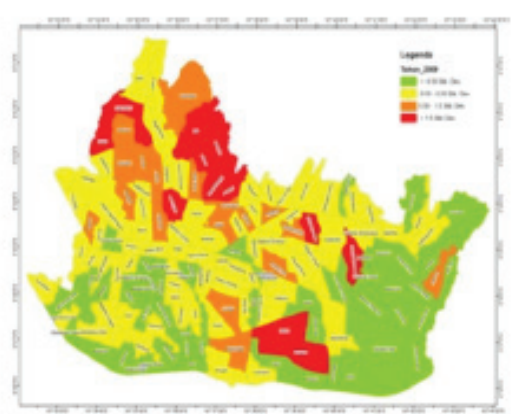

2009

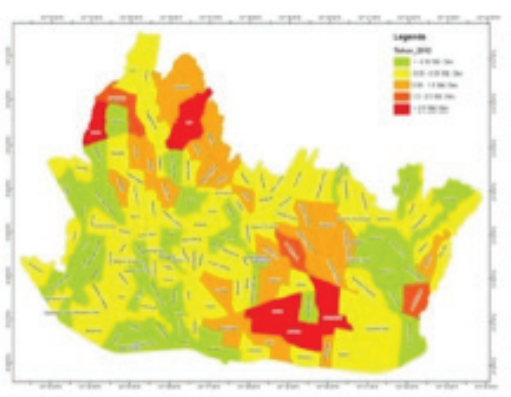

2012

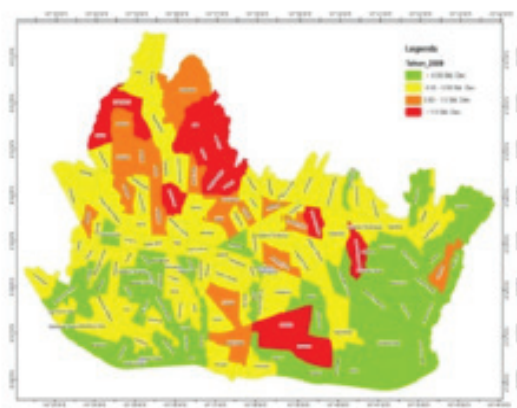

2010

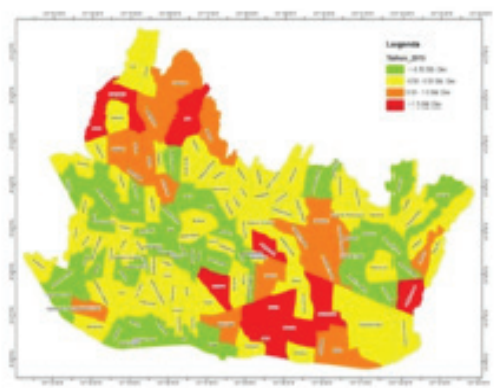

2013

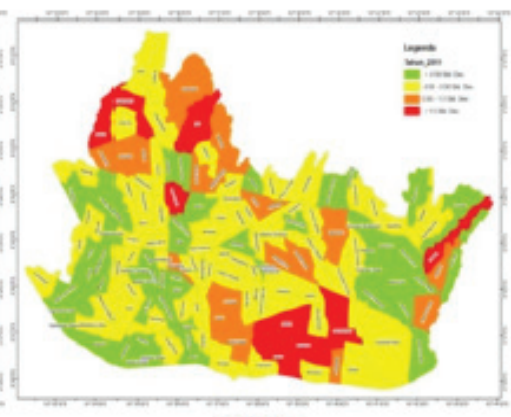

2011

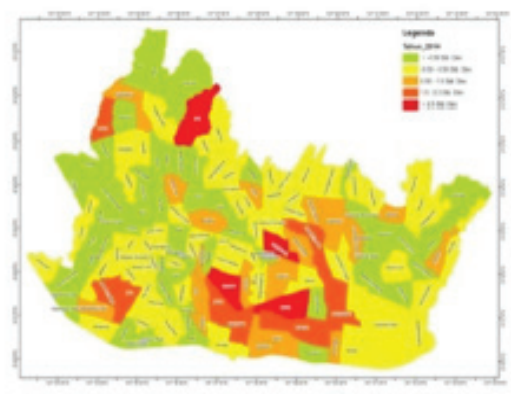

2014

Figure 6 Yearly Spatial Distribution of DHF from 2009-2014

\section{Discussion}

Information for DHF cases reported to Bandung City Health Office was gathered based on the routine surveillance system. The surveillance system was essential to provide epidemiology data and disease evolution in specific time frames. Results showed that dengue cases in Bandung city showed an increased pattern with hyperendemic years in between. This pattern was similar to DHF cases in Indonesia which showed intermittent hyperendemic in some years cases reported showed a significant increased. ${ }^{5}$

Dengue hemorrhagic fever was one of communicable disease included in National Communicable Diseases Surveillance System since 1968. According to the rules, every DHF cases have to be reported to Health District Office within 24 hours by all hospitals, health centers, and other health facilities. ${ }^{6}$ At present, the quality and quantity of the report were much better. Sources of DHF reports came from 20 hospitals and 73 health centers in Bandung city. These reported cases most probably were not yet cover the whole cases in this city since the surveillance system was a passive one. Passive surveillance system depends heavily on the compliance of health officers in hospitals, health centers, and other health facilities.7

Reports to Bandung City Health Office have not yet covered all cases in the city because of several reasons. Firstly, dengue with clinical manifestation not specific such as bleeding, organ failures, and other neurology symptom was not recorded as DHF cases and most probably will not be reported. ${ }^{8}$ Secondly, mild dengue symptom which did not come to health facilities cannot be captured using passive surveillance available. Thirdly, dengue suspect which did not have serological test will not capture in surveillance database which will be the result of underreporting. Compliance in reporting system was not yet optimize since there was not yet proper monitoring and evaluation mechanism which can be used. This is not a unique problem for Bandung city since the same problem also happened in countries with passive surveillance system..$^{9-10}$

Dengue hemorrhagic fever fatality rate was decreasing probably because of the better skill of health officers in detecting dengue symptoms and the availability of treatment in health facilities. There were already many skilled health officers in DHF treatment management. At present guidelines for diagnosis, treatment, prevention, and control of DHF have already available in 
all health centers. ${ }^{8}$ The urban community has a better information and communication in general. This is also the reason for having better and faster treatment for DHF. ${ }^{11}$ Third, local government pays more attention to DHF fatality cases, especially when mass media reported such cases.

Based on age group, DHF cases highest found on group 5-19years old, who mostly still in school, and $20-59$ years old, the productive age groups. Both groups have more activities and meet more people who can be explained the sources and the probability of transmission. ${ }^{12}$ Arguably, DHF control program might be the reason of lower level of immunity to DHF infection that the community was more susceptible to the diseases.

Target of global strategy to decrease dengue burden based on WHO was to lower mortality rate to $50 \%$ and morbidity rate to $25 \%$ in year 2020 and to measure the real burden of dengue in year $2015 .{ }^{13}$ To achieve the target, cases in Bandung city have to lower to 2,500 cases with case fatality rate of $0.1 \%$ in 2020 . Baseline data used for the target was 2010 data with 3,435 dengue cases in Bandung city.

To reach those number, several factors need to be considered. Bandung city is becoming the hub of urban activities which attract a lot of people. These factors will increase the population not only from birth but mostly for migration. Data from WHO which stated that urban population would increase have already happened in this city. Increased population density will also increase population exposure to this disease. ${ }^{1}$ Exposure cannot also separate from other cases in other areas. For examples, the dengue outbreak in Indonesia on 1976-1977 caused by DEN-3 started in Jakarta which then spread all over Indonesia even overseas. ${ }^{14}$

Map of dengue cases in Bandung city showed that several areas have high cases all years in north, middle and east Bandung. Those areas reported highest residential area development. This study strengthened another study which stated that dengue was easily transmitted given the chance of vector and dengue virus contact with a human. Flight distance of mosquito is shortened in dense areas such as urban compare to less dense such as rural areas. ${ }^{15}$ The human factor is very important on the spread of this disease. Human mobility for examples gives exposure to the virus that will define the variety of exposures. This factor is very important especially in the area very conducive for vector and dengue virus development such as slum and dense area. ${ }^{16}$

At the population level, people who came to infectious areas and gain exposure to theinfections and dengue transmission will develop specific transmission pattern. In Bandung city, this is translated to the pattern of people movement from their houses to their neighbor's, friends and other relatives. A study in Iquitos, Mexico concluded that community interaction pattern will define dengue transmission. ${ }^{17}$ Another study in Bangkok, Thailand simulated the impact of people migrations with dengue virus. The results showed that dengue virus travels as fast as 148 $\mathrm{km}$ per month from inside and around Bangkok and other urban areas. This type of areas needs to have special attention to prevent the spread of diseases travels further.

At present, Bandung city has become the magnet for people from other areas especially because of economic and education factors. Bandung has already become tourist destinations because of its cool weather, culinary and arts, and other attractions. Since many people came to Bandung to stay, some residential areas were built in relatively short time based on needs without any comprehensive plan regarding its domestic environment, for examples the availability of clean water, basic sanitation, and other facilities. The makeshift on the land usage of such residential areas which already been built will make city development plans faced difficult to execute. The areas which were built without following the city plan might also be the source of the high incidence of dengue. Land usage changes from open spaces to residential areas for examples closely related to the abundance of dengue vector, Aedes spp. ${ }^{18-19}$ Dense residential area without proper basic sanitation and clean water and unclean environment will increase the risk of dengue transmission.

\section{Conclusion}

Dengue hemorrhagic fever cases in Bandung city showed an increased trend with fluctuated hyperendemic year especially in the year 2009, 2012, and 2013. The pattern of disease started from north of Bandung towards east Bandung. Pockets of highest reported cases were found in north to middle and east for the whole year. The spread of this disease, especially in east Bandung, showed wider affected areas in the observed year. Land usage for residential purposes without good development plan might be on factors that 
increase the disease transmission.

\section{Conflict of Interest}

The authors declare no conflict of interests.

\section{Aknowledgement}

This study was supported by Bandung District Health City, Stasiun Meteorologi, Klimatologi dan Geofisika (BMKG) Kota Bandung and Lembaga Penerbangan dan Antariksa Nasional (LAPAN) Bandung.

\section{References}

1. World Health Organization. Urban population growth. 2015 [cited 2016 Januari 21]. Available from: http://www.who.int/ gho/urban_health/situation_trends/urban_ population_growth_text/en/.

2. Pusat Data dan Informasi, Kementerian Kesehatan RI. Situasi demam berdarah dengue di Indonesia. Jakarta: Pusdatin Kemenkes RI; 2013.

3. Dinas Kesehatan Kota Bandung. Laporan demam berdarah dengue. Bandung: Dinas Kesehatan Kota Bandung; 2015.

4. Okello-Onen J, Mboera LEG, Mugisha S. Malaria research and management need rethinking: Uganda and Tanzania case studies. In: Charron DF, editor. Ecohealth rsearch in ractice. Innovative application of an ecosystem approach to health. New York: Springer; 2012. p. 139-51.

5. Karyanti MR, Uiterwaal CSPM, Kusriastuti R, Hadinegoro SR, Rover MM, Heesterbeek $\mathrm{H}$, et al. The changing incidence of dengue haemorrhagic fever in Indonesia: a 45-year registry-based analysis. BMC Infect Dis. 2014;14:412.

6. Direktorat Jenderal Pengendalian Penyakit dan Penyehatan Lingkungan, Kementerian Kesehatan RI. Buku saku pedoman pengendalian demam berdarah dengue untuk pengelola program DBD puskesmas. Jakarta; Ditjen PP dan PL Kemenkes RI; 2013.

7. Kementerian Kesehatan RI. Profil kesehatan Indonesia 2014. Jakarta: Kemenkes RI; 2015.

8. World Health Organization. Dengue: guidelines for diagnosis, treatment, prevention and control. New edition. Geneva: WHO Press; 2009.

9. Hay SI, Myers MF, Burke DS, Vaughn
DW, Endy T, Ananda N, et al. Etiology of interepidemic periods of mosquitoborne disease. Proc Natl Acad Sci U S A. 2000;97(16):9335-9.

10. Schaffner F, Mathis A. Dengue and dengue vectors in the WHO European region: past, present, and scenarios for the future. Lancet Infect Dis. 2014;14(12):1271-80.

11. Respati T, Piliang B, Nurhayati E, Yulianto FA, Feriandi Y. Perbandingan pengetahuan dengan sikap dalam pencegahan demam berdarah dengue di daerah urban dan rural. GMHC. 2016;4(1):53-9.

12. World Health Organization. Report of a WHO technical working group meeting on dengue prevention and control. WHO headquarters, Geneva, Switzerland, 10-12 December 2012 [cited 2016 May 28]. Available from: http:// www.who.int/denguecontrol/Summary_ Technical_working_group_meeting.pdf.

13. World Health Organization. Global strategy for dengue prevention and control 20122020. Geneva: WHO Press; 2012.

14. Ooi EE, Gubler DJ. Dengue in Southeast Asia: epidemiological characteristics and strategic challenges in disease prevention. Cad Saúde Pública. 2008;25(Suppl 1):S115-24.

15. Respati T, Nurhayati E, Mahmudah, Feriandi Y, Budiman, Yulianto $\mathrm{F}$, et al. Pemanfaatan kalender 4M sebagai alat bantu meningkatkan peran serta masyarakat dalam pemberantasan dan pencegahan demam berdarah. GMHC. 2016;4(2):121-8.

16. Respati T, Raksanagara A, Djuhaeni H, Sofyan A, Shandriasti A. Ecohealth system dynamic model as a planning tool for the reduction of breeding sites. IOP Conf Ser Mater Sci Eng. 2017;180(1):012108.

17. Reiner RC Jr, Stoddard ST, Scott TW. Socially structured human movement shapes dengue transmission despite the diffusive effect of mosquito dispersal. Epidemics. 2014;6:306.

18. Balasubramanian R, Anukumar B, Nikhil TL. Stegomyia indices of Aedes mosquito infestation and container productivity in Alappuzha district Kerala. Int $\mathrm{J}$ Mosquito Res. 2015;2(2):14-8.

19. Faridah L, Respati T, Sudigdoadi S, Sukandar H. Gambaran partisipasi masyarakat terhadap pengendalian vektor melalui kajian tempat perkembangbiakan Aedes aegypti di Kota Bandung. MKB. 2017;49(1):43-7. 